\title{
Aquatic exercise training and stable heart failure: A systematic review and meta-analysis
}

\author{
Julie A Adsett BPhty (Hons) ${ }^{1,2,3}$ \\ Alison M Mudge PhD, FRACP, MBBS (Hons), Grad Cert Health Econ ${ }^{4}$ \\ Norman Morris $\quad$ PhD, B Appl Sci (Physiotherapy), Dip Ed, BSc ${ }^{3}$ \\ Suzanne Kuys PhD, BPhty ${ }^{5}$ \\ Jennifer D Paratz PhD, B Phty, FACP 2,3 \\ ${ }^{1}$ Heart Failure Service, Royal Brisbane and Women's Hospital, Brisbane, Australia \\ ${ }^{2}$ Physiotherapy Department, Royal Brisbane and Women's Hospital, Brisbane, Australia \\ ${ }^{3}$ School of Allied Health Sciences, Griffith University, Gold Coast, Australia \\ ${ }^{4}$ Department of Internal Medicine and Aged Care, Royal Brisbane and Women's Hospital, \\ Brisbane, Australia \\ ${ }^{5}$ School of Physiotherapy, Australian Catholic University, Brisbane, Australia
}

Correspondence to Julie Adsett : Heart Failure Service, Level 3, James Mayne Building, Royal Brisbane and Women's Hospital, Herston, Brisbane, Australia 4029

Ph: +61736460286 Fax: +61736460272Ｅmail: Julie.adsett@health.qld.gov.au

No financial support was required for this study.

Conflict of interest: none 


\begin{abstract}
Aim: A meta-analysis and review of the evidence was conducted to determine the efficacy of aquatic exercise training for individuals with heart failure compared to traditional land-based programmes.

Methods : A systematic search was conducted for studies published prior to March 2014, using MEDLINE, PUBMED, Cochrane Library, CINAHL and PEDro databases. Key words and synonyms relating to aquatic exercise and heart failure comprised the search strategy. Interventions included aquatic exercise or a combination of aquatic plus land-based training, whilst comparator protocols included usual care or land-based training alone. The primary outcome of interest was exercise performance. Studies reporting on muscle strength, quality of life and a range of haemodynamic and physiological parameters were also reviewed.
\end{abstract}

Results: Eight studies met criteria, accounting for 156 participants. Meta-analysis identified studies including aquatic exercise to be superior to comparator protocols for 6 minute walk test $(\mathrm{p}<0.004)$ and peak power $(\mathrm{p}<0.044)$. Compared to land-based training programmes, aquatic exercise training provided similar benefits for $\mathrm{VO}_{2 \text { peak, }}$, muscle strength and quality of life, though was not superior. Cardiac dimensions, left ventricular ejection fraction, cardiac output and BNP were not influenced by aquatic exercise training.

Conclusions: For those with stable heart failure, aquatic exercise training can improve exercise capacity, muscle strength and quality of life similar to land-based training programmes . This form of exercise may provide a safe and effective alternative for those unable to participate in traditional exercise programmes.

Key words: Heart Failure, cardiomyopathy, exercise training, aquatic exercise, hydrotherapy 


\section{Introduction}

Exercise training is a recommended component of the comprehensive management of patients with heart failure (HF). Exercise based rehabilitation programmes have consistently shown positive improvements in patient symptoms, exercise capacity and quality of life, and a possible impact upon hospital readmissions and mortality ${ }^{1,2}$.

Traditional land-based training programmes however, may not be suitable for all patients. The frail elderly and those with co-morbid conditions including chronic pain, orthopaedic or balance disturbances for example, may find these programmes difficult, contributing to lower levels of physical activity participation ${ }^{3}$. Aquatic exercise (exercise conducted in thermoneutral $\left[32-34{ }^{\circ} \mathrm{C}\right]$ water) has been proposed as a possible alternative for these patients. The warm water and low weight bearing environment reduces pain, and using the principles of hydrodynamics, allows exercise to be undertaken which may improve postural stability, exercise capacity and walking endurance ${ }^{4-7}$.

Historically, aquatic exercise has not been recommended for individuals with HF. Immersion in warm water leads to an increase in venous return as a consequence of hydrostatic pressure. Clinicians have long been concerned that this increase in central blood volume and cardiac preload may not be tolerated by those with HF, leading to worsening of symptoms and a reduction in exercise capacity ${ }^{8}$. This potential risk has hampered trials and there are currently no clear recommendations for clinical practice. Recent small studies however, have demonstrated that patients with stable HF not only tolerate immersion and exercise in this environment, but also benefit from a number of physiological sequelae ${ }^{9-11}$. The purpose of this systematic review and meta-analysis was to determine the effect of aquatic exercise training on a variety of functional and physiological outcome measures in this population. Specifically, the study sought to determine functional benefits of aquatic exercise compared to usual activity and/or land-based exercise in people with heart failure. 


\section{Methods}

Search strategy and study selection

MEDLINE, PUBMED, Cochrane Library, CINAHL and PEDro databases were searched using the key words "aquatic exercise "OR " hydrotherapy" OR "water exercise" AND "heart failure" OR "cardiomyopathy”, OR "ventricular dysfunction. “ The search was limited to studies published prior to March 2014 in any language. Identified titles and abstracts were independently scrutinised by two reviewers (JA and JP) and reference lists were assessed for additional relevant articles that met criteria. Full text articles were extracted and independently reviewed by both reviewers when required, and any further disagreement was resolved by discussion between reviewers.

Randomised controlled trials, pseudo randomised controlled trials, trials with historical controls and single group studies were included in the review. Case studies, didactic articles and narrative reviews were excluded. Studies were accepted if they included an aquatic exercise intervention of at least two weeks duration, conducted in a heated pool. Only trials that recruited adult patients with left ventricular dysfunction (reduced or preserved ejection fraction) were accepted. For intervention groups, training included either aquatic exercise alone or aquatic + land-based training. Comparator groups included land-based training, usual activity or no exercise. As single group studies were included in the review, it was also possible for there to be no comparator group. Exercise activities conducted in spas, sauna baths or other non- hydrotherapy pools were also excluded. Included studies were independently scored for quality by the two reviewers using the validated PEDro scale ${ }^{12}$. Original authors were contacted for clarification of material or to provide missing data when required.

\section{Outcome measures}

The primary outcome measure was change in exercise performance measured using either peak oxygen consumption $\left(\mathrm{VO}_{\text {2peak }}\right)$, six minute walk test $(6 \mathrm{MWT})$ or peak power. Secondary outcomes included change in muscle strength, cardiac dimensions, haemodynamic parameters (including 
cardiac output, systemic vascular resistance and blood pressure), brain natriuretic peptide (BNP) and quality of life (QoL).

\section{Data synthesis}

Comprehensive Meta-analysis software ${ }^{\mathrm{TM}}$ was used to compare results between studies. For continuous variables, effect size for each individual study was determined using the Hedges g model, by calculating the difference between changes in the intervention group and comparator group by the pooled standard deviation. The data were pooled using the fixed effect model, however when heterogeneity was statistically significant, $(\mathrm{Q}$ statistic $\mathrm{p}<0.01)$, the data were reanalysed using the random effects model. Meta-analyses were conducted for $\mathrm{VO}_{2 \text { peak }}$, peak power and 6MWT. Due to insufficient studies reporting on specific outcomes, heterogeneity of methodology and lack of availability of some raw data, meta-analysis was not possible on other parameters.

\section{Results}

\section{Studies included in the review}

Of the 73 papers identified, 37 were immediately excluded on the basis of duplication. An additional 12 abstracts were excluded based upon criteria, leading to a review of 24 full text articles. Of these, 16 were excluded for the purposes of not being clinical trials, investigating alternative outcome measures or for not including a water based exercise intervention of greater than two weeks duration. As demonstrated in the flow diagram in Figure 1, this systematic review and meta-analysis was conducted on the eight remaining studies, which included five randomized controlled trials (RCTs) ${ }^{9-}$ ${ }^{11,13,14}$, two pre-post test design studies without a control group ${ }^{15,16}$ and one prospective cohort intervention with follow up ${ }^{17}$. Six of the eight studies originated from two research centres, thus decreasing generalisability. All studies were published in English. 


\section{Study quality and participants}

Quality scores for included studies are listed in Table 1. Main concerns included lack of assessor blinding 9-11,13-17, allocation to groups not being concealed ${ }^{11}$, no documented evidence of outcome measures being obtained from $>85 \%$ of participants ${ }^{10}$ and no documented evidence of "intention to treat" analysis ${ }^{10}$.

Baseline characteristics for the eight included studies are depicted in Table 2. Studies were relatively small $(n=12-25)$, and the overall total number of participants was 156 . The study groups were well matched for participant numbers, age, gender, left ventricular ejection fraction (LVEF) and HF aetiology. Participants were predominantly male $(n=139)$ with mean age 52-70 years. All participants had heart failure with reduced ejection fraction (HFREF) which in most studies this was defined as LVEF $<40-45 \%$, whilst one study recruited only those with LVEF $<35 \%{ }^{16}$. Aetiology of HF was defined in all but one study ${ }^{16}$, and included ischaemic $(n=95)$ and dilated $(n=39)$ cardiomyopathies. Studies mostly recruited participants with NYHA II-III symptoms. Participants with co-morbid disease, including orthopaedic or neurological conditions, were excluded from three of the eight studies ${ }^{9-11}$.

\section{Study design}

Training parameters for each study are reported in Table 3. All protocols were undertaken by experienced exercise professionals at local health facilities with water temperature maintained between $30^{\circ} \mathrm{C}$ and $34^{\circ} \mathrm{C}$. Depth of immersion varied and was either fixed (1.3 metres) ${ }^{13-15}$, or individualized to the level of the xiphisternum ${ }^{11}$ or neck ${ }^{9,10,16}$. Immersion depth was not defined in one study ${ }^{17}$ and humidity was not reported in any of the included studies.

Training protocols varied between studies. The aquatic intervention was confined to a water programme in only half of the studies with the exercise duration for these being 45 minutes. In the remaining four studies, the intervention included a combination of both aquatic and land-based 
training, the latter being 30 minutes of cycle ergometry. Heterogeneity also existed for the length of the programme, varying from three weeks to 24 weeks. In each of the short duration programmes, participants trained for either four ${ }^{15}$ or five days per week ${ }^{13,14,16}$, compared to three times per week in longer programmes.

Protocols predominantly consisted of endurance training prescribed at an intensity of $40-70 \%$ maximum heart rate reserve $(\mathrm{HRR})$ or $50-70 \% \mathrm{VO}_{2 \text { peak }}$. Resistance training was included in two studies ${ }^{9,10}$.

\section{Comparator protocols}

Comparator protocols also varied. For the four studies that employed an isolated aquatic intervention, two were compared to usual activity ${ }^{9,10}$, one used participants as self-controls following a period of no exercise ${ }^{17}$ and there was no comparator in one study ${ }^{16}$. For the combined interventions (aquatic + land training), three of these studies compared outcomes to a land-based intervention alone ${ }^{11,13,14}$, whilst the remaining study used self-controls as the comparator ${ }^{15}$. In each of the combined interventions (aquatic + land), exercise intensity was matched across the two environments and total duration of exercise was equal for participant groups.

\section{Summary of findings}

Meta-analysis was conducted for the primary outcomes of $\mathrm{VO}_{2 \text { peak }}$, peak power and 6MWT (Figure 2).

Secondary outcomes were unsuitable for meta-analysis but relevant study findings are summarised in Table 4 and Supplementary Table 1. 
$V O_{2 p e a k}, 6 M W T$ and peak power

Six studies measured $\mathrm{VO}_{2 \text { peak }}{ }^{9,10,13-16}$, including four RCTs. Meta-analysis was conducted on the three studies that provided raw data, and revealed no significant difference between the aquatic and comparator groups $(\mathrm{p}<0.87)$ (Figure 2). Review of individual studies suggested that when compared to controls who undertook usual activity, aquatic exercise led to a significant improvement in $\mathrm{VO}_{2 \text { peak }}$ 9,10, (between group difference $\mathrm{p}<0.001$ and $\mathrm{p}=0.02$ respectively). When compared to land- based training alone, programmes that included a combined aquatic + land programme, elicited similar changes in $\mathrm{VO}_{2 \text { peak }}{ }^{13,14}$ but were not superior. In these latter two trials, a combined aquatic + land intervention induced an improvement in $\mathrm{VO}_{2 \text { peak }}$ by $6-11 \%$. The land only protocols in these same two trials led to an improvement of $10.5-11 \%$.

Four studies reported 6MWT but only two were suitable for meta-analysis ${ }^{9,11}$. One further study did not provide raw data ${ }^{10}$ and one had no comparator group ${ }^{16}$. Overall, the analysis favoured the aquatic intervention $(\mathrm{p}<0.004)$ (Figure 2). Of these studies, one compared an aquatic intervention to usual activity ${ }^{9}$, however it was the study that compared a combined protocol to a land only training that elicited the greatest effect size ${ }^{11}$. The study which did not provide raw data ${ }^{10}$ also reported a significant improvement in 6MWT compared to usual care.

For peak power data, meta-analysis conducted on three RCTs that included this parameter favoured the aquatic intervention $(\mathrm{p}<0.044)$ (Figure 2). One study compared an aquatic intervention to usual activity ${ }^{9}$ and the remaining two compared a combined training protocol (aquatic + land) to land based training alone ${ }^{13,14}$. Compared to usual activity, aquatic exercise significantly improved peak power $(\mathrm{p}<0.05)^{9}$. Compared to land-based training protocols however, the impact of aquatic exercise was less clear. Teffaha et al $2011^{13}$ demonstrated greater benefit with aquatic compared to land-based training alone (between group difference $\mathrm{p}<0.05$ ), while Mourot et al $200{ }^{14}$, found a significant within group difference for both groups, but no between group difference. 


\section{Muscle strength}

Muscle strength was measured in only three of the eight included studies ${ }^{9-11}$ (Table 4). Two of these studies (conducted by the same group), included a variety of lower limb isokinetic and isometric parameters, as well as measures of muscle endurance and grip strength ${ }^{9,10}$. When compared to usual activity, aquatic exercise significantly improved upper limb and lower limb endurance measures. Whilst there was a trend favouring the aquatic intervention for measures of isokinetic knee extension peak torque, results did not consistently reach significance. Grip strength and isometric lower limb peak torque measures did not significantly improve. The third study investigating muscle strength, found a significant improvement in maximum voluntary contraction (MVC) of the quadriceps for both combined (aquatic + land) and land only exercise groups following an endurance training intervention $(\mathrm{p}<0.05)$, however no between group difference ${ }^{11}$. Similarly, there was no significant difference between the aquatic and land interventions for measures of quadriceps peak torque. No resistance training was employed in this study.

\section{LVEF and Cardiac dimensions}

Aquatic exercise training did not significantly influence LVEF in three of the four studies that reported this parameter ${ }^{11,16,17}$ By comparison, Teffaha et al ${ }^{13}$, did show a significant improvement in LVEF following a three week training period $(\mathrm{p}<0.05)$, with a slightly greater effect size elicited in the combined aquatic and land group compared to land only intervention (0.44 vs 0.21$)$.

The effect of aquatic exercise training on cardiac dimensions is difficult to discern due to variation in study methodology and reporting. Transthoracic echocardiography was used to record baseline and post programme cardiac dimensions in four studies. Results were reported according to left ventricular end diastolic and systolic diameters (LVEDD and LVESD) by two authors ${ }^{11,13}$, whilst volume measures were reported by the remaining two authors ${ }^{16,17}$. Aquatic exercise did not significantly influence any of these parameters following the exercise training periods. 
Whilst the exercise interventions did not significantly influence cardiac dimensions over the long term, immersion itself did have an acute impact upon these measures. This ensues due to the increase in venous return that occurs as a consequence of hydrostatic pressure and was demonstrated by Svealv et al, $2009{ }^{17}$ who recorded cardiac volumes during immersion, both before and after aquatic exercise training. Left ventricular end diastolic and systolic volumes (LVEDV and LVESV) both significantly increased during immersion compared to measures recorded on land at these same time points.

\section{Haemodynamic parameters}

Interpreting the effect of aquatic exercise training on haemodynamic parameters is difficult, as results are influenced not only by variations in study design, but also the environment in which parameters are measured. The majority of studies reported measures conducted on land, whilst others also included immersion measures. To enable more suitable comparison of haemodynamic measures, studies listed below are summarised in Supplementary Table 1.

\section{i) Land measures}

Following a period of aquatic exercise training, resting systolic blood pressure (SBP) does not appear to change when measured on land, but there may be an impact upon resting diastolic blood pressure (DBP). Caminiti et al ${ }^{11}$ reported a significant reduction in DBP following a 24 week combined aquatic + land intervention, which was not observed in those undertaking the land only training programme (between group difference $\mathrm{p}<0.05$ ). Shorter duration studies however, have not elicited similar results ${ }^{14,15}$.

With regard to resting heart rate (HR), aquatic exercise training does not appear to provide additional benefit to land-based training. Of the five studies that measured this parameter ${ }^{11,13-15,18}$, only two demonstrated a reduction in HR following the intervention ${ }^{11,13}$, and one demonstrated a significantly greater effect in the aquatic group $(\mathrm{p}<0.05){ }^{11}$. These studies also showed an increase in resting stroke volume (SV). 
Of the four studies that measured systemic vascular resistance (SVR) ${ }^{11,14,15,17}$, three yielded no change following the intervention period. The study by Caminiti et al ${ }^{11}$ however, reported a significant reduction following the 24 week intervention, favouring the aquatic group (between group difference $\mathrm{p}<0.05$ ). In this study, a combined training approach (aquatic + land training) was compared to land based training alone. Cardiac output was not observed to significantly change following any exercise intervention for studies included in this review ${ }^{11,14,15}$.

\section{ii.) Immersion measures}

In addition to the decrease in resting HR observed with acute immersion ${ }^{18-20}$, further reductions are observed following a period of aquatic exercise training, when this parameter is measured during immersion ${ }^{11,15}$. Compared to land-based training however, this reduction in HR is no greater than that observed following land-based training, measured in this same environment ${ }^{11,15}$. Similar results are observed for increases in resting SV measured during immersion ${ }^{11}$.

Measured during immersion, resting SBP, DBP and cardiac output do not appear to be influenced by aquatic exercise training.

\section{Natriuretic peptide and plasma nitrate}

N-Terminal pro -brain natriuretic peptide (NT-proBNP) ${ }^{14,16}$ and $\mathrm{BNP}{ }^{17}$ were measured prior to and following the exercise training protocol in three studies. No significant difference was recorded in this parameter following the training period for any of these studies.

Plasma nitrate was reported by one author, who described a significant increase following the aquatic intervention $(\mathrm{p}<0.05)$, whilst no significant change was observed in the land only training group ${ }^{14}$. Comparison of change between the two groups was not reported.

\section{Quality of life}


Quality of life was measured in three studies using the Minnesota living with heart failure questionnaire (MLWHFQ) ${ }^{9,10,16}$. Whilst a significant improvement $(\mathrm{p}=0.01)$ was recorded in the aquatic intervention group in two of these studies ${ }^{9,10}$, aquatic exercise was not superior to usual activity with regards to QoL.

Safety

No serious adverse events were reported in any of the studies included in this review. Only one study documented negative consequences of the aquatic intervention. These included a new episode of arrhythmia in an individual with paroxysmal atrial fibrillation and episodes of mild fatigue in three individuals undertaking the first two weeks of their training protocol ${ }^{9}$.

\section{Discussion}

The findings from this review indicate that aquatic exercise training is beneficial for individuals with stable HF, as it improves exercise capacity, muscle strength and QoL to a similar extent as land-based exercise training. Some haemodynamic measures such as resting diastolic blood pressure, heart rate and systemic vascular resistance may also improve following this intervention. A combined approach including aquatic exercise in addition to land-based training, may even be superior to land-based training alone for 6MWT and peak power. The primary outcome in this review was exercise performance. Of the small number of studies included, meta-analysis of aquatic exercise training versus alternative protocols, favoured the aquatic intervention for 6MWT and peak power and demonstrated no significant impact upon $\mathrm{VO}_{2 \text { peak }}$. As 6MWT is a commonly used measure of performance in these patients, this outcome seems very encouraging. However, these results are based upon only two studies and a limited number of participants, and as such should be interpreted with caution and should not be extrapolated to all individuals. 
Land-based training programmes have been extensively studied in HF participants and improvements in $\mathrm{VO}_{2 \text { peak }}$ post intervention are commonly cited as being $15-25 \%{ }^{21,22}$. Interestingly, smaller changes were reported in the studies included in this review for both the aquatic and land interventions (6-11\% and $10.5-11 \%$ respectively). This may suggest conservative or insufficient exercise volume or intensity in these studies. In each study, exercise intensity was prescribed according to heart rate reserve and these same targets were used for both the aquatic and comparator protocols. It is possible that heart rate may not be the best indicator of exercise intensity given the acute haemodynamic effects of immersion on this parameter. Determining exercise intensity during aquatic exercise remains a challenge for the clinician.

Whilst aquatic exercise appears to evoke greater strength gains than usual care, its benefit compared to land-based training protocols is less certain. In the one study that compared these two training environments, no resistance training was included in the protocol. One might assume that during aquatic exercise, the water itself may provide a degree of resistance and consequent strength gains; however experts in this field stress the importance of a strong working knowledge of the physiological principles of hydrodynamics to achieve optimal results. Consistent with previous studies which have demonstrated that resistance training is the best modality for improving muscle strength in this population, ${ }^{23-25}$ merely transferring land-based exercises into the aquatic environment is not sufficient. Best results would likely ensue when specific resistance exercises are employed ${ }^{4,26,27}$.

From the studies currently available, aquatic exercise does not appear to significantly influence cardiac dimensions or LVEF. This is not an unexpected finding, given the relatively short duration of most interventions. In the one study of long duration included in this review, a number of positive haemodynamic benefits were reported that favoured the aquatic intervention ${ }^{11}$. These included a reduction in resting DBP and $\mathrm{HR}$ and an increase in resting stroke volume post programme. In this study, Caminiti et al ${ }^{11}$ proposed that aquatic exercise may provide a greater stimulus for central adaptive changes, particularly with improved haemodynamics at rest. When combined with the peripheral physiological adaptations that are well documented to occur with land-based training, a 
combined training approach may elicit even greater physiological and functional benefit. This is yet to be confirmed however, and has not been observed in shorter duration studies.

No serious adverse events were reported for any of the 156 participants included in this review and adherence rates were listed between 92-95\%, indicating a high acceptance in the selected trial participants. Quality of life improved in the few studies that included this parameter though was not superior to land-based training.

There are several limitations to this review. Firstly, trials were small with carefully selected participants and results cannot be extrapolated to all individuals with HF. Svealv et al 2012 highlights potential concerns for those with biventricular failure and pulmonary hypertension ${ }^{18}$. This case report suggests that potential subgroups may exist for whom aquatic exercise training may not be recommended and at this time clinicians should use good clinical judgement when recommending this form of exercise for patients with HF. Decompensated HF remains an absolute contra-indication for aquatic exercise training.

In addition to the small number of trials included in this review, three of the eight studies were not RCTs, and one did not include controls. Raw data were not available for all measures. Participants were predominantly males, had HF with reduced ejection fraction, and aetiology was primarily ischaemic. Individuals with orthopaedic or neurological co-morbidities were often excluded, yet these are the very patients who might benefit most from this intervention.

Despite these limitations, this review indicates that aquatic exercise training improves exercise performance in individuals with stable HF and may provide a safe and acceptable alternative for those unable to access or participate in traditional land-based programmes.

Further research should target those who are typically seen in clinical practice such as those with HF with preserved ejection fraction, the frail elderly, and those with significant co-morbidities. Trials should investigate the impact of this form of exercise on other parameters pertinent to HF such as diuresis, thermoregulation, fatigue and respiratory muscle function, all of which may be influenced by 
exercise training in this environment. Training intensity should be measured to inform prescription. Finally, acceptability of aquatic exercise training for these individuals should also be explored.

\section{Conclusion}

For individuals with stable HF, aquatic exercise training improves exercise capacity, muscle strength and quality of life similar to land-based training protocols. Aquatic exercise training may provide a safe and effective alternative to traditional land-based programmes for appropriately selected patients. Results cannot be extrapolated to all individuals with HF. Future research should enrol more representative samples to identify feasible training protocols to inform translation of this research into everyday practice. 


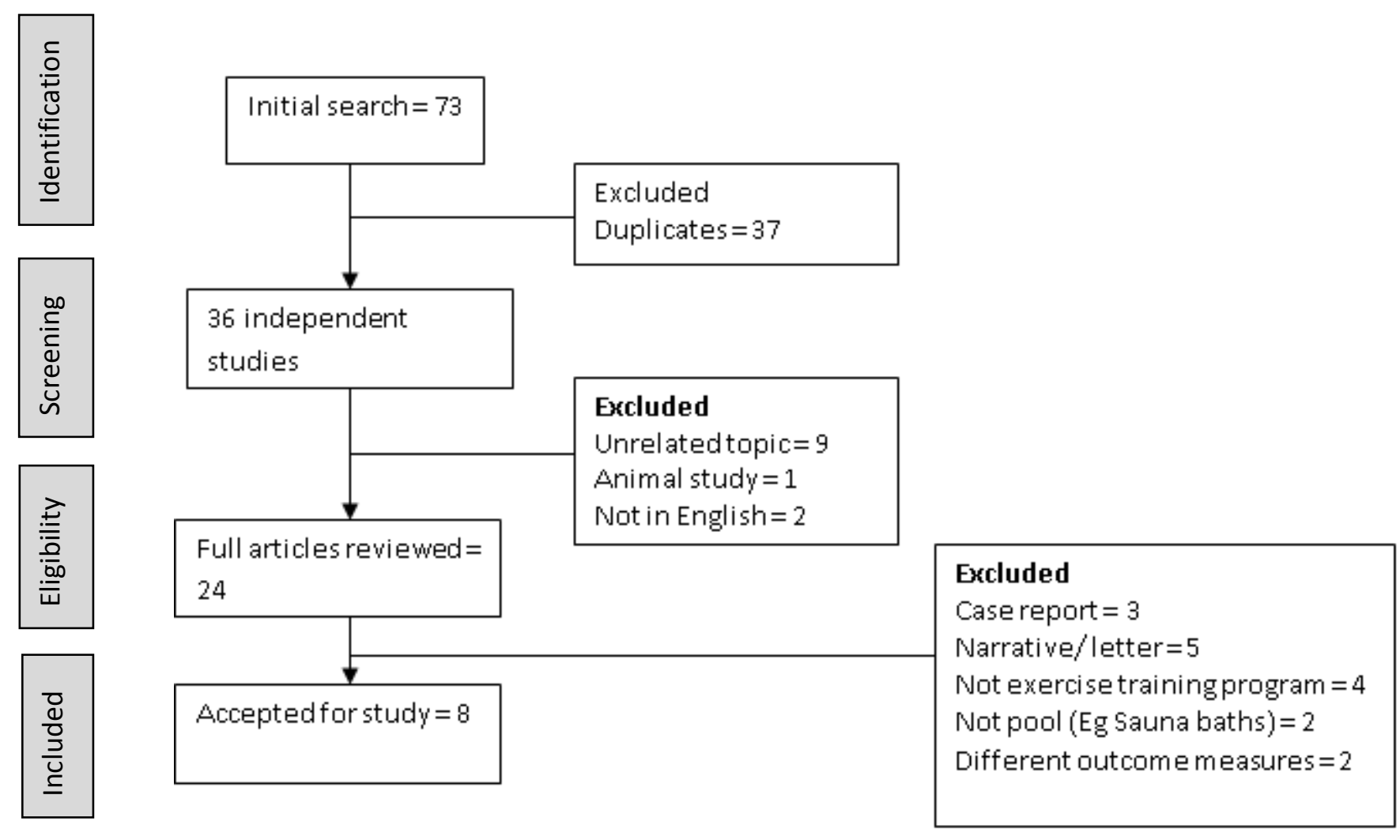

Figure 1. Flow diagram of included studies 


\section{VO2 peak}

\begin{tabular}{|c|c|c|c|c|c|c|c|}
\hline \multirow[t]{2}{*}{ Study name } & \multirow[b]{2}{*}{$\begin{array}{l}\text { Hedges's } \\
\text { g }\end{array}$} & \multirow[b]{2}{*}{$\begin{array}{l}\text { Standard } \\
\text { error }\end{array}$} & \multicolumn{3}{|c|}{ Statistics for each study } & \multirow[b]{2}{*}{ z-Value } & \multirow[b]{2}{*}{ p-Value } \\
\hline & & & Variance & $\begin{array}{l}\text { Lower } \\
\text { limit }\end{array}$ & $\begin{array}{l}\text { Upper } \\
\text { li mit }\end{array}$ & & \\
\hline Cider et al, 2003 & 0.630 & 0.405 & 0.164 & -0.164 & 1.423 & 1.555 & 0.120 \\
\hline Teffaha et al, 2011 & .0 .040 & 0.394 & 0.155 & .0 .812 & 0.733 & -0.100 & 0.9 \\
\hline \multirow[t]{2}{*}{ Mourot et al, 2009} & -0.460 & 0.400 & 0.160 & -1.243 & 0.324 & -1.150 & $0.2-2$ \\
\hline & 0.038 & 0.231 & 0.053 & -0.414 & 0.490 & 0.164 & 0.8 \\
\hline
\end{tabular}

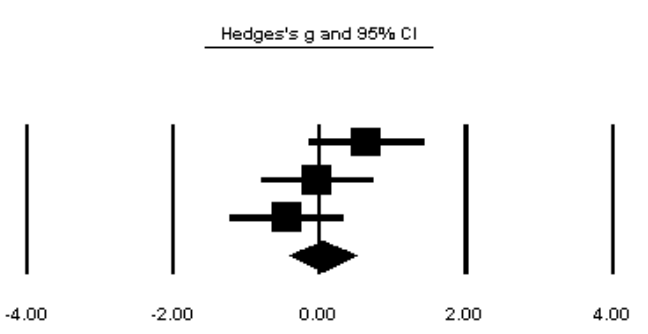

Favours Comparator

6MWT

\begin{tabular}{|c|c|c|c|c|c|c|c|}
\hline \multirow[t]{2}{*}{ Study name } & \multirow[b]{2}{*}{$\begin{array}{l}\text { Hedges's } \\
g\end{array}$} & \multirow[b]{2}{*}{$\begin{array}{l}\text { Standard } \\
\text { error }\end{array}$} & \multicolumn{3}{|c|}{ Statistics for each study } & \multirow[b]{2}{*}{ z-value } & \multirow[b]{2}{*}{$p \cdot v=$} \\
\hline & & & Variance & $\begin{array}{l}\text { Lower } \\
\text { limit }\end{array}$ & $\begin{array}{l}\text { Upper } \\
\text { li mit }\end{array}$ & & \\
\hline Caminiti et al, 2011 & 1.855 & 0.508 & 0.258 & 0.860 & 2.850 & 3.653 & 0.00 \\
\hline \multirow[t]{2}{*}{ Cider et al, 2003} & 0.306 & 0.397 & 0.158 & -0.473 & 1.084 & 0.770 & 0.46 \\
\hline & 0.894 & 0.313 & 0.098 & 0.281 & 1.507 & 2.857 & \\
\hline
\end{tabular}

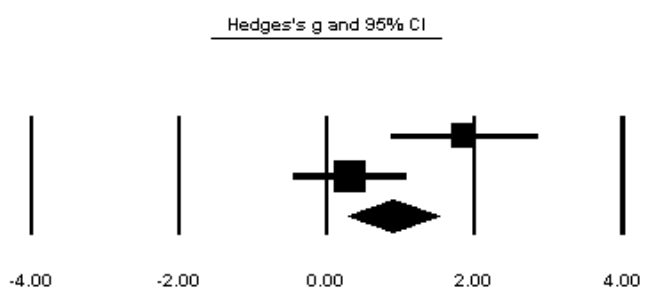

Favours Comparator

Favours Aquatic Exercise

\section{Peak Power}

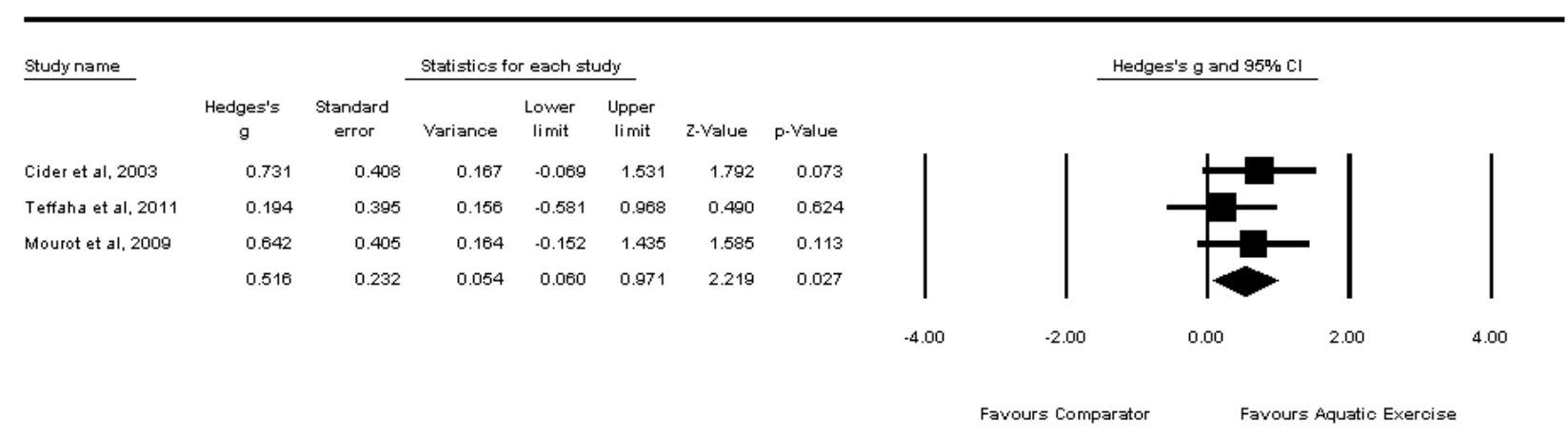

Figure 2. Change in (a)VO2 peak, (b) 6MWT and (c) Peak power for aquatic exercise training versus comparator protocols. 
Table 1. PEDro scores for included studies

\begin{tabular}{|l|c|}
\hline Author & PEDro score ( /10) \\
\hline Randomized controlled trials & 5 \\
\hline Cider et al, 2012 & 7 \\
\hline Teffaha et al 2011 & 6 \\
\hline Caminiti et al, 2011 & 7 \\
\hline Mourot et al, 2009 & 7 \\
\hline Cider et al, 2003 & \\
\hline Non randomized controlled trials & 2 \\
\hline Mourot et al, 2010 & 5 \\
\hline Svealv et al, 2009 & 2 \\
\hline Municino et al, 2006 & \\
\hline
\end{tabular}


Table 2. Baseline characteristics of included studies

\begin{tabular}{|c|c|c|c|c|c|c|c|c|c|c|c|c|}
\hline \multirow[t]{2}{*}{ Author } & \multicolumn{2}{|c|}{ Number } & \multicolumn{2}{|c|}{ Age (yrs) } & \multicolumn{2}{|c|}{ Gender } & \multicolumn{2}{|c|}{ LVEF (\%) } & \multicolumn{2}{|c|}{ HF Aetiology } & \multicolumn{2}{|c|}{ NYHA } \\
\hline & $\begin{array}{l}\text { Aquatic } \\
\text { exercise }\end{array}$ & Comparator & $\begin{array}{l}\text { Aquatic } \\
\text { exercise }\end{array}$ & Comparator & $\begin{array}{l}\text { Aquatic } \\
\text { exercise }\end{array}$ & Comparator & $\begin{array}{l}\text { Aquatic } \\
\text { exercise }\end{array}$ & Comparator & $\begin{array}{l}\text { Aquatic } \\
\text { exercise }\end{array}$ & Comparator & $\begin{array}{l}\text { Aquatic } \\
\text { exercise }\end{array}$ & Comparator \\
\hline $\begin{array}{l}\text { Cider et al, } \\
2012\end{array}$ & 10 & 10 & $65.8+/-5.8$ & $69+/-8.2$ & $\begin{array}{l}8 \text { Males } \\
2 \text { Females }\end{array}$ & $\begin{array}{l}8 \text { Males } \\
2 \text { Females }\end{array}$ & $34.1+/-9.8$ & $\begin{array}{l}34.8+/ 1 \\
9.1\end{array}$ & $\begin{array}{l}\text { IHD } 8 \\
\text { DCM } 1 \\
\text { HT } 1\end{array}$ & $\begin{array}{l}\text { IHD } 4 \\
\text { DCM } 4 \\
\text { HT } 2\end{array}$ & $\begin{array}{l}\text { II } 5 \\
\text { III } 5\end{array}$ & $\begin{array}{l}\text { II } 3 \\
\text { III } 7\end{array}$ \\
\hline $\begin{array}{l}\text { Teffaha et al, } \\
2011\end{array}$ & 12 & 12 & $51.7+/-3.6$ & $53.3+/-4.2$ & $\begin{array}{l}12 \text { Males } \\
0 \text { Females }\end{array}$ & $\begin{array}{l}12 \text { Males } \\
0 \text { Females }\end{array}$ & $30.2+/-2$ & $\begin{array}{l}28.9+/- \\
2.2\end{array}$ & $\begin{array}{l}\text { IHD } 8 \\
\text { DCM } 4\end{array}$ & $\begin{array}{l}\text { IHD } 7 \\
\text { DCM } 5\end{array}$ & $\begin{array}{l}\text { II } 1 \\
\text { III } 11\end{array}$ & $\begin{array}{l}\text { II } 2 \\
\text { III } 10\end{array}$ \\
\hline $\begin{array}{l}\text { Caminiti et al, } \\
2011\end{array}$ & 11 & 10 & $67+/-6$ & $69+/-8$ & 11 Males & 10 Males & $33+/-9$ & $32+/-12$ & $\begin{array}{l}\text { IHD } 8 \\
\text { DCM } 3\end{array}$ & $\begin{array}{l}\text { IHD } 6 \\
\text { DCM } 4\end{array}$ & $\begin{array}{l}\text { II } 7 \\
\text { III } 4\end{array}$ & $\begin{array}{l}\text { II } 6 \\
\text { III } 4\end{array}$ \\
\hline $\begin{array}{l}\text { Mourot et al, } \\
2010\end{array}$ & 12 & N/A & $53+/-4$ & N/A & 12 Males & N/A & $30.2+/-6.7$ & N/A & $\begin{array}{l}\text { IHD } 8 \\
\text { DCM } 4\end{array}$ & N/A & $*$ & $*$ \\
\hline $\begin{array}{l}\text { Svealv et al, } \\
2009\end{array}$ & 12 & N/A & $69+/-7$ & N/A & $\begin{array}{l}8 \text { Males } \\
4 \text { Females }\end{array}$ & N/A & $40+/-7$ & N/A & $\begin{array}{l}\text { IHD } 11 \\
\text { DCM } 2\end{array}$ & N/A & $\begin{array}{l}\text { II } 7 \\
\text { III } 5\end{array}$ & N/A \\
\hline $\begin{array}{l}\text { Mourot et al, } \\
2009\end{array}$ & 12 & 12 & $53+/-4$ & $55+/-4$ & $\begin{array}{l}12 \text { Males } \\
0 \text { Females }\end{array}$ & $\begin{array}{l}12 \text { Males } \\
0 \text { Females }\end{array}$ & $30.2+/-6.7$ & $28.9+/-7$ & $\begin{array}{l}\text { IHD } 8 \\
\text { DCM } 4\end{array}$ & $\begin{array}{l}\text { IHD } 7 \\
\text { DCM } 5\end{array}$ & $*$ & $*$ \\
\hline $\begin{array}{l}\text { Municino et } \\
\text { al, } 2006\end{array}$ & 18 & N/A & $63+/-10$ & N/A & $\begin{array}{l}17 \text { Males } \\
1 \text { Females }\end{array}$ & N/A & $27+/-6$ & N/A & $*$ & $*$ & $\begin{array}{l}\text { II } 9 \\
\text { III } 7\end{array}$ & N/A \\
\hline
\end{tabular}




\begin{tabular}{|c|c|c|c|c|c|c|c|c|c|c|c|c|}
\hline & & & & & & & & & & & IV 2 & \\
\hline $\begin{array}{l}\text { Cider et al, } \\
2003\end{array}$ & 15 & 10 & $70.2+/-5.2$ & $75+/-6.4$ & $\begin{array}{l}11 \text { Males } \\
5 \text { Females }\end{array}$ & $\begin{array}{l}6 \text { Males } \\
3 \text { Females }\end{array}$ & $31+/ 8.3$ & Not listed & $\begin{array}{l}\text { IHD } 12 \\
\text { DCM } 2 \\
\text { VD } 1 \\
\text { HT 0 }\end{array}$ & $\begin{array}{l}\text { IHD } 8 \\
\text { DCM } 1 \\
\text { VD } 0 \\
\text { HT } 1\end{array}$ & $\begin{array}{l}\text { II } 3 \\
\text { III } 12\end{array}$ & $\begin{array}{l}\text { II } 1 \\
\text { III } 9\end{array}$ \\
\hline
\end{tabular}


Table 3. Exercise training protocols for included studies

\begin{tabular}{|c|c|c|c|c|c|c|c|}
\hline Author & Exercise protocol & Comparator & Duration & Frequency & Mode & $\begin{array}{c}\text { Water } \\
\text { temperature } \\
\text { and immersion } \\
\text { depth }\end{array}$ & Outcome Measures \\
\hline Cider et al, 2012 & $\begin{array}{l}\text { Aquatic exercise } 45 \mathrm{~min} \\
\text { sessions } \\
40-75 \% \mathrm{HRR}\end{array}$ & Usual activity & 8 weeks & x3 per week & $\begin{array}{l}\text { Aerobic and } \\
\text { resistance training }\end{array}$ & $\begin{array}{l}33-34^{\circ} \mathrm{C} \\
\text { Neck deep } \\
\text { immersion }\end{array}$ & $\begin{array}{l}\text { VO2 peak } \\
\text { 6MWT } \\
\text { Muscle strength } \\
\text { QoL }\end{array}$ \\
\hline $\begin{array}{l}\text { Teffaha et al, } \\
2011\end{array}$ & $\begin{array}{l}\text { Combined training }= \\
\text { aquatic }+ \text { land } \\
50 \text { minute session aquatic } \\
\text { exercise }+30 \text { minutes cycle } \\
\text { ergometer }\end{array}$ & $\begin{array}{l}\text { Land only } \\
50 \text { minute session } \\
\text { callisthenic exercise }+30 \\
\text { minutes cycle ergometer }\end{array}$ & 3 weeks & x5 per week & $\begin{array}{l}\text { Aerobic exercise } \\
\text { Intensity } \\
\text { individualized to } \\
\text { THR }\end{array}$ & $\begin{array}{l}30-32^{\circ} \mathrm{C} \\
\text { Depth }=1.3 \mathrm{~m}\end{array}$ & $\begin{array}{l}\text { VO2 peak } \\
\text { Echocardiography } \\
\text { Non invasive } \\
\text { haemodynamic } \\
\text { measures }\end{array}$ \\
\hline $\begin{array}{l}\text { Caminiti et al, } \\
2011\end{array}$ & $\begin{array}{l}\text { Combined training = } \\
\text { aquatic exercise + land } \\
\text { training } \\
30 \text { minutes daily, with } \\
\text { exercise conducted in } \\
\text { different environment on } \\
\text { alternate days }\end{array}$ & $\begin{array}{l}\text { Land training only } \\
2 \times 30 \text { mins alternate days } \\
60-70 \% \text { VO2 peak }\end{array}$ & 24 weeks & x3 per week & Aerobic exercise & $\begin{array}{l}31^{\circ} \mathrm{C} \\
\text { Xiphisternum }\end{array}$ & $\begin{array}{l}\text { Echocardiography } \\
6 \mathrm{MWT} \\
\text { Non invasive } \\
\text { haemodynamic } \\
\text { measures } \\
\text { Muscle strength }\end{array}$ \\
\hline $\begin{array}{l}\text { Mourot et al, } \\
2010\end{array}$ & $\begin{array}{l}\text { Aquatic exercise } \\
\begin{array}{l}40 \text { minute sessions } \\
\quad+\end{array} \\
\text { Cycle ergometer on land } \\
30 \text { minute sessions } \\
60-70 \% \text { HRR }\end{array}$ & $\begin{array}{l}\text { Self controls } \\
\text { Land versus immersion } \\
\text { measures }\end{array}$ & 3 weeks & $\begin{array}{l}\text { Aquatic } x 3-4 \\
\text { per week } \\
\text { Land } \times 4-5 \text { per } \\
\text { week }\end{array}$ & Aerobic exercise & $\begin{array}{l}30-32{ }^{\circ} \mathrm{C} \\
\text { Depth }=1.3 \mathrm{~m}\end{array}$ & $\begin{array}{l}\text { VO2 peak } \\
\text { Non invasive } \\
\text { haemodynamic } \\
\text { measures }\end{array}$ \\
\hline $\begin{array}{l}\text { Svealv et al, } \\
2009\end{array}$ & $\begin{array}{l}\text { Aquatic exercise } \\
45 \text { minute sessions } \\
40-70 \% \text { HRR }\end{array}$ & $\begin{array}{l}\text { Self controls } \\
\text { No exercise }\end{array}$ & 8 weeks & $\mathrm{x} 2$ per week & Aerobic exercise & $33-34^{\circ} \mathrm{C}$ & $\begin{array}{l}\text { Echocardiography } \\
\text { BNP }\end{array}$ \\
\hline $\begin{array}{l}\text { Mourot et al, } \\
2009\end{array}$ & $\begin{array}{l}\text { Combined training }= \\
\text { aquatic }+ \text { land } \\
50 \text { minute session aquatic } \\
\text { exercise }+30 \text { minutes cycle }\end{array}$ & $\begin{array}{l}\text { Land only } \\
50 \text { minute session } \\
\text { callisthenic exercise }+30 \\
\text { minutes cycle ergometer }\end{array}$ & 3 weeks & x5 per week & Aerobic exercise & $\begin{array}{l}30-32^{\circ} \mathrm{C} \\
\text { Depth }=1.3 \mathrm{~m}\end{array}$ & $\begin{array}{l}\text { VO2 peak } \\
\text { NT-BNP, } \\
\text { catecholamine and NO } \\
\text { metabolites } \\
\text { Non invasive }\end{array}$ \\
\hline
\end{tabular}




\begin{tabular}{|l|l|l|l|l|l|l|l|}
\hline & ergometer & 60-70\% HRR & & & & \\
\hline $\begin{array}{l}\text { Municino et al, } \\
2006\end{array}$ & $\begin{array}{l}\text { Aquatic exercise } \\
45 \text { minute sessions } \\
50 \% \text { VO2peak + 60-70\% } \\
\text { VO2peak }\end{array}$ & No comparator & 3 weeks & $\begin{array}{l}\text { x2 per day } \\
\text { x5 per week } \\
\text { measures }\end{array}$ & Aerobic exercise & $\begin{array}{l}31-32^{\circ} \mathrm{C} \\
\text { Sternal notch }\end{array}$ & $\begin{array}{l}\text { 6MWT } \\
\text { VO2peak } \\
\text { Echocardiography } \\
\text { NT-BNP } \\
\text { QoL }\end{array}$ \\
\hline Cider et al, 2003 & $\begin{array}{l}\text { Aquatic exercise } \\
45 \text { minute sessions } \\
40-70 \% \text { HRR }\end{array}$ & Usual activity & 8 weeks & x3 per week & $\begin{array}{l}\text { Aerobic and } \\
\text { resistance training }\end{array}$ & $\begin{array}{l}33-34^{\circ} \mathrm{C} \\
\text { Neck deep }\end{array}$ & $\begin{array}{l}\text { VO2 peak } \\
6 \mathrm{MWT} \\
\text { Muscle strength } \\
\text { QoL }\end{array}$ \\
\hline
\end{tabular}


Table 4. Muscle strength outcomes

\begin{tabular}{|c|c|c|c|c|c|}
\hline Outcome Measure & Author & Aquatic intervention & $\begin{array}{l}\text { Comparator } \\
\text { intervention }\end{array}$ & $\begin{array}{c}\text { Change from baseline } \\
\text { aquatic }\end{array}$ & Favours \\
\hline LL isokinetic peak torque $\left(60^{\circ} / \mathrm{s}\right)$ & $\begin{array}{l}\text { Cider et al, } 2012 \\
\text { Cider et al, } 2003\end{array}$ & $\begin{array}{l}\text { Aquatic exercise training } \\
\text { Aquatic exercise training }\end{array}$ & $\begin{array}{l}\text { Usual activity } \\
\text { Usual activity }\end{array}$ & $\begin{array}{l}+5 \mathrm{Nm} \text { vs }-4 \mathrm{Nm} \\
+1 \mathrm{Nm} \text { vs }-7 \mathrm{Nm}\end{array}$ & $\begin{array}{l}\text { ns } \\
\text { Aquatic }\end{array}$ \\
\hline LL isokinetic peak torque $\left(180^{\circ} / \mathrm{s}\right)$ & $\begin{array}{l}\text { Cider et al, } 2012 \\
\text { Cider et al, } 2003\end{array}$ & $\begin{array}{l}\text { Aquatic exercise training } \\
\text { Aquatic exercise training }\end{array}$ & $\begin{array}{l}\text { Usual activity } \\
\text { Usual activity }\end{array}$ & $\begin{array}{l}+31 \mathrm{Nm} * \mathrm{vs}-2 \mathrm{Nm} \\
+18 \mathrm{vs}-3 \mathrm{Nm}\end{array}$ & $\begin{array}{l}\text { Aquatic }{ }^{\dagger \dagger \dagger} \\
\text { ns }\end{array}$ \\
\hline Heel lift endurance (number) & $\begin{array}{l}\text { Cider et al, } 2012 \\
\text { Cider et al, } 2003\end{array}$ & $\begin{array}{l}\text { Aquatic exercise training } \\
\text { Aquatic exercise training }\end{array}$ & $\begin{array}{l}\text { Usual activity } \\
\text { Usual activity }\end{array}$ & 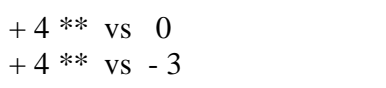 & $\begin{array}{l}\text { Aquatic }{ }^{\dagger} \\
\text { Aquatic }{ }^{\dagger}\end{array}$ \\
\hline $\begin{array}{l}\text { Shoulder flexion endurance } \\
\text { (number) }\end{array}$ & $\begin{array}{l}\text { Cider et al, } 2012 \\
\text { Cider et al, } 2003\end{array}$ & $\begin{array}{l}\text { Aquatic exercise training } \\
\text { Aquatic exercise training }\end{array}$ & $\begin{array}{l}\text { Usual activity } \\
\text { Usual activity }\end{array}$ & $\begin{array}{l}+10 * \text { vs } 0 \\
+6 * * \text { vs }+4\end{array}$ & $\begin{array}{l}\text { Aquatic }^{\dagger} \\
\text { Aquatic }{ }^{\dagger \dagger}\end{array}$ \\
\hline $\begin{array}{l}\text { Shoulder abduction endurance } \\
\text { (number) }\end{array}$ & $\begin{array}{l}\text { Cider et al, } 2012 \\
\text { Cider et al, } 2003\end{array}$ & $\begin{array}{l}\text { Aquatic exercise training } \\
\text { Aquatic exercise training }\end{array}$ & $\begin{array}{l}\text { Usual activity } \\
\text { Usual activity }\end{array}$ & $\begin{array}{l}+14 * * \text { vs }-8 * \\
+12 * \text { vs }-8\end{array}$ & $\begin{array}{l}\text { Aquatic }{ }^{\dagger \dagger} \\
\text { Aquatic }{ }^{\dagger \dagger}\end{array}$ \\
\hline Hand grip strength (peak force) & $\begin{array}{l}\text { Cider et al, } 2012 \\
\text { Cider et al, } 2003\end{array}$ & $\begin{array}{l}\text { Aquatic exercise training } \\
\text { Aquatic exercise training }\end{array}$ & $\begin{array}{l}\text { Usual activity } \\
\text { Usual activity }\end{array}$ & $\begin{array}{l}+43 \mathrm{~N} \text { vs }-27 \mathrm{~N}^{*} \\
+13 \mathrm{~N} \text { vs }+4 \mathrm{~N}\end{array}$ & $\begin{array}{l}\mathrm{ns} \\
\mathrm{ns}\end{array}$ \\
\hline $\begin{array}{l}\text { Isometric knee extension peak } \\
\text { torque }\end{array}$ & $\begin{array}{l}\text { Cider et al, } 2012 \\
\text { Cider et al, } 2003\end{array}$ & $\begin{array}{l}\text { Aquatic exercise training } \\
\text { Aquatic exercise training }\end{array}$ & $\begin{array}{l}\text { Usual activity } \\
\text { Usual activity }\end{array}$ & $\begin{array}{l}0 N \text { vs }-8 N \\
+2 N \text { vs }-2 N\end{array}$ & $\begin{array}{l}\mathrm{ns} \\
\mathrm{ns}\end{array}$ \\
\hline MVC quadriceps & Caminiti et al, 2011 & Aquatic + land training & Land training & $+23 \mathrm{~N}^{*} \mathrm{vs}+21 \mathrm{~N} *$ & $\mathrm{~ns}$ \\
\hline Peak torque quadriceps & Caminiti et al, 2011 & Aquatic + land training & Land training & $+17 \mathrm{Nm}$ vs $+9 \mathrm{Nm}$ & $\mathrm{ns}$ \\
\hline
\end{tabular}


Supplementary Table 1. Resting haemodynamic outcomes : change from baseline

\begin{tabular}{|c|c|c|c|c|c|}
\hline \multirow[t]{2}{*}{ Outcome measure } & \multirow[t]{2}{*}{ Author } & \multicolumn{2}{|l|}{ Measured on land } & \multicolumn{2}{|c|}{ Measured in water } \\
\hline & & Aquatic versus comparator intervention & Favours & $\begin{array}{c}\text { Aquatic versus comparator } \\
\text { intervention }\end{array}$ & Favours \\
\hline $\begin{array}{l}\text { Blood pressure } \\
\text { SBP } \\
\text { DBP }\end{array}$ & $\begin{array}{l}\text { Caminiti et al, } 2011 \\
\text { Mourot et al, } 2010 \\
\text { Mourot et al, } 2009 \\
\text { Caminiti et al, } 2011 \\
\text { Mourot et al, } 2010 \\
\text { Mourot et al, } 2009\end{array}$ & $\begin{array}{l}-8.4 \mathrm{mmHg} \text { vs }-9.2 \mathrm{mmHg} \\
-5.4 \mathrm{mmHg} \text { (No control group) } \\
+2.7 \mathrm{mmHg} \text { vs }+10.9 \mathrm{mmHg} \\
\\
-11 \mathrm{mmHg} * \text { vs }-4 \mathrm{mmHg} \\
-0.8 \mathrm{mmHg} \text { (No control group) } \\
-0.8 \mathrm{mmHg} \text { vs }+6.8 \mathrm{mmHg}\end{array}$ & $\begin{array}{l}\text { ns } \\
- \\
\text { ns } \\
\text { Aquatic }^{\dagger} \\
- \\
\text { ns }\end{array}$ & $\begin{array}{l}-6 \mathrm{mmHg} \text { vs }-4 \mathrm{mmHg} \\
-4.2 \mathrm{mmHg} \text { (No control group) } \\
-7 \mathrm{mmHg} \text { vs }-2 \mathrm{mmHg} \\
-3.8 \mathrm{mmHg} \text { (No control group) }\end{array}$ & $\begin{array}{l}\text { ns } \\
- \\
\text { ns } \\
-\end{array}$ \\
\hline Heart rate & $\begin{array}{l}\text { Teffaha et al, } 2011 \\
\text { Caminiti et al, } 2011 \\
\text { Mourot et al, } 2010 \\
\text { Mourot et al, } 2009\end{array}$ & $\begin{array}{l}-4 \mathrm{bpm} * \mathrm{vs}-3 \mathrm{bpm} * \\
-12 \mathrm{bpm} * \mathrm{vs}+3 \mathrm{bpm} \\
-1.1 \mathrm{bpm}(\text { No control group) } \\
-10.3 \mathrm{bpm} \text { vs }-4.9 \mathrm{bpm}\end{array}$ & $\begin{array}{l}\text { Not reported } \\
\text { Aquatic }^{\dagger} \\
- \\
\text { ns }\end{array}$ & $\begin{array}{l}-15 \mathrm{bpm} * \mathrm{vs}-12 \mathrm{bpm} * \\
-3.4 \mathrm{bpm} * \text { (No control group) }\end{array}$ & $\begin{array}{l}\text { ns } \\
-\end{array}$ \\
\hline Stroke volume & $\begin{array}{l}\text { Teffaha et al, } 2011 \\
\text { Caminiti et al, } 2011 \\
\text { Mourot et al, } 2010 \\
\text { Mourot et al, } 2009\end{array}$ & $\begin{array}{l}+2 \mathrm{ml} * \text { vs }+8 \mathrm{ml} * \\
+16 \mathrm{ml} * \text { vs }+7 \mathrm{ml} \\
-2.05 \mathrm{ml} \text { (No control group) } \\
+17.7 \mathrm{ml} \text { vs }+8 \mathrm{ml}\end{array}$ & $\begin{array}{l}\text { Not reported } \\
\text { ns } \\
- \\
\text { ns }\end{array}$ & $\begin{array}{l}+19 \mathrm{ml} \text { vs }+12 \mathrm{ml} \\
+2.5 \mathrm{ml} \text { (No control group) }\end{array}$ & ns \\
\hline Cardiac output & $\begin{array}{l}\text { Caminiti et al, } 2011 \\
\text { Mourot et al, } 2010 \\
\text { Mourot et al, } 2009\end{array}$ & $\begin{array}{l}+1.1 \mathrm{~L} / \mathrm{min} \text { vs }+0.6 \mathrm{~L} / \mathrm{min} \\
-0.25 \mathrm{~L} / \mathrm{min} \text { (No control group) } \\
0 \mathrm{~L} / \mathrm{min} \mathrm{vs}+0.3 \mathrm{~L} / \mathrm{min}\end{array}$ & $\begin{array}{l}\mathrm{ns} \\
- \\
\mathrm{ns}\end{array}$ & $\begin{array}{l}+0.7 \mathrm{~L} / \mathrm{min} \mathrm{vs}+0.3 \mathrm{~L} / \mathrm{min} \\
+0.01 \mathrm{~L} / \mathrm{min} \text { (No control group) }\end{array}$ & $\begin{array}{l}\text { ns } \\
-\end{array}$ \\
\hline $\begin{array}{l}\text { Systemic vascular } \\
\text { resistance }\end{array}$ & $\begin{array}{l}\text { Svealv et al, } 2009 \\
\text { Mourot et al, } 2009\end{array}$ & $\begin{array}{l}0 \text { RU vs } 0 \text { RU } \\
+206 \text { dyne sec/cm }{ }^{5} \text { vs }-248 \text { dyne } \mathrm{sec} / \mathrm{cm}^{5}\end{array}$ & $\begin{array}{l}\mathrm{ns} \\
\mathrm{ns}\end{array}$ & $-2 \mathrm{RU}$ vs $+2 \mathrm{RU}$ & ns \\
\hline LVEDV & $\begin{array}{l}\text { Svealv et al, } 2009 \\
\text { Municino et al, } 2006\end{array}$ & $\begin{array}{l}-10 \mathrm{ml} \text { vs }-8 \mathrm{ml} \\
\text { Data not reported (ns), no control }\end{array}$ & $\begin{array}{l}\mathrm{ns} \\
-\end{array}$ & $\begin{array}{l}-6 \mathrm{ml} \text { vs }-4 \mathrm{ml} \\
\text { Data not reported (ns), no control }\end{array}$ & $\begin{array}{l}\text { ns } \\
-\end{array}$ \\
\hline
\end{tabular}




\section{References}

1. Piepoli MF, Davos C, Francis DP, Coats AJ. Exercise training meta-analysis of trials in patients with chronic heart failure (ExTraMATCH). BMJ. Jan 24 2004;328(7433):189.

2. O'Connor $\mathrm{CM}$, Whellan DJ, Lee $\mathrm{KL}$, et al. Efficacy and safety of exercise training in patients with chronic heart failure: HF-ACTION randomized controlled trial. JAMA. Apr 8 2009;301(14):1439-1450.

3. Murad K, Kitzman DW. Frailty and multiple comorbidities in the elderly patient with heart failure: implications for management. Heart Fail Rev. Sep 2012;17(4-5):581-588.

4. Geytenbeek J. Evidence for effective hydrotherapy. Physiotherapy. 2002;88(9):514-529.

5. Vivas J, Arias P, Cudeiro J. Aquatic therapy versus conventional land-based therapy for Parkinson's disease: an open-label pilot study. Arch Phys Med Rehabil. Aug 2011;92(8):12021210.

6. Avelar NC, Bastone AC, Alcantara MA, Gomes WF. Effectiveness of aquatic and non-aquatic lower limb muscle endurance training in the static and dynamic balance of elderly people. Rev Bras Fisioter. May-Jun 2010;14(3):229-236.

7. McNamara RJ, Alison JA, McKeough ZJ. Water-based exercise in chronic obstructive pulmonary disease. Phys Ther Rev. 2011;16(1):25-30.

8. Tei C, Horikiri Y, Park JC, et al. Acute hemodynamic improvement by thermal vasodilation in congestive heart failure. Circulation. May 15 1995;91(10):2582-2590.

9. Cider A, Schaufelberger M, Sunnerhagen KS, Andersson B. Hydrotherapy--a new approach to improve function in the older patient with chronic heart failure. Eur J Heart Fail. Aug 2003;5(4):527-535.

10. Cider A, Schaufelberger M, Stibrant S, Andersson B. Aquatic exercise is effective in improving exercise performance in patients with heart failure and type 2 diabetes mellitus. Evid Based Complement Alternat Med. 2012;2012:349209.

11. Caminiti G, Volterrani M, Marazzi G, et al. Hydrotherapy added to endurance training versus endurance training alone in elderly patients with chronic heart failure: a randomized pilot study. Int J Cardiol. Apr 14 2011;148(2):199-203.

12. Maher CG, Sherrington C, Herbert RD, Moseley AM, Elkins M. Reliability of the PEDro scale for rating quality of randomized controlled trials. Physical Therapy. 2003;83:713-721.

13. Teffaha $D$, Mourot $L$, Vernochet $P$, et al. Relevance of water gymnastics in rehabilitation programs in patients with chronic heart failure or coronary artery disease with normal left ventricular function. J Card Fail. Aug 2011;17(8):676-683.

14. Mourot $L$, Teffaha $D$, Bouhaddi $M$, et al. Training-induced increase in nitric oxide metabolites in chronic heart failure and coronary artery disease: an extra benefit of water-based exercises? Eur J Cardiovasc Prev Rehabil. Apr 2009;16(2):215-221.

15. Mourot $L$, Teffaha $D$, Bouhaddi $M$, et al. Exercise rehabilitation restores physiological cardiovascular responses to short-term head-out water immersion in patients with chronic heart failure. J Cardiopulm Rehabil Prev. Jan-Feb 2010;30(1):22-27.

16. Municino A, Nicolino A, Milanese $M$, et al. Hydrotherapy in advanced heart failure: the cardio-HKT pilot study. Monaldi Arch Chest Dis. Dec 2006;66(4):247-254.

17. Svealv BG, Cider A, Tang MS, Angwald E, Kardassis D, Andersson B. Benefit of warm water immersion on biventricular function in patients with chronic heart failure. Cardiovasc Ultrasound. 2009;7:33.

18. Svealv BG, Tang MS, Cider A. Is hydrotherapy an appropriate form of exercise for elderly patients with biventricular systolic heart failure? J Geriatr Cardiol. Dec 2012;9(4):408-410. 
19. Cider A, Svealv BG, Tang MS, Schaufelberger M, Andersson B. Immersion in warm water induces improvement in cardiac function in patients with chronic heart failure. Eur $J$ Heart Fail. May 2006;8(3):308-313.

20. Gabrielsen A, Sorensen VB, Pump B, et al. Cardiovascular and neuroendocrine responses to water immersion in compensated heart failure. Am J Physiol Heart Circ Physiol. Oct 2000;279(4):H1931-1940.

21. Rees K, Taylor RS, Singh S, Coats AJ, Ebrahim S. Exercise based rehabilitation for heart failure. Cochrane Database Syst Rev. 2004(3):CD003331.

22. van Tol BA, Huijsmans RJ, Kroon DW, Schothorst M, Kwakkel G. Effects of exercise training on cardiac performance, exercise capacity and quality of life in patients with heart failure: a meta-analysis. Eur J Heart Fail. Dec 2006;8(8):841-850.

23. McKelvie RS, McCartney N, Tomlinson C, Bauer R, MacDougall JD. Comparison of hemodynamic responses to cycling and resistance exercise in congestive heart failure secondary to ischemic cardiomyopathy. Am J Cardiol. Nov 1 1995;76(12):977-979.

24. Braith RW, Beck DT. Resistance exercise: training adaptations and developing a safe exercise prescription. Heart Fail Rev. Feb 2008;13(1):69-79.

25. Feiereisen $P$, Delagardelle $C$, Vaillant $M$, Lasar $Y$, Beissel J. Is strength training the more efficient training modality in chronic heart failure? Med Sci Sports Exerc. Nov 2007;39(11):1910-1917.

26. Bartels EM, Lund H, Hagen KB, Dagfinrud H, Christensen R, Danneskiold-Samsoe B. Aquatic exercise for the treatment of knee and hip osteoarthritis. Cochrane Database Syst Rev. 2007(4):CD005523.

27. Rahmann AE. Exercise for people with hip or knee osteoarthritis: a comparison of land-based and aquatic interventions. Open Access Journal of Sports Medicine. 2010;1:123-135. 